\section{Take a chomp out of $B D$ J Bites}

The $B D J$ has launched its own YouTube channel and one of its features is $B D J$ Bites, short audio summaries highlighting recent research as an adjunct for the time-strapped reader.

In the first instalment of $B D J$ Bites, Editor-in-Chief Stephen Hancocks introduces a $B D J$ article which investigates the availability

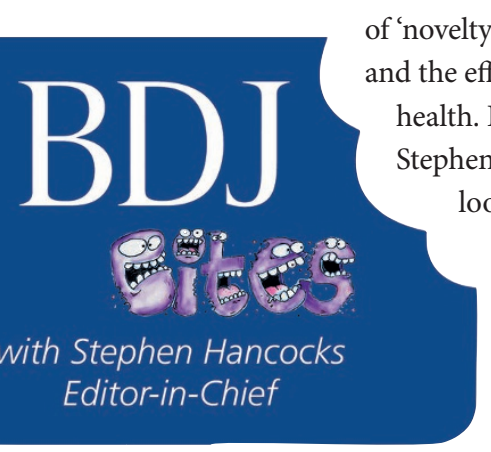
of 'novelty sweets' near schools nd the effect of this on children's health. In the next episode, tephen discusses an article looking at why children drink sports drinks and the effect on their oral health.

Also available on the YouTube channel are a video of the actual

launch (into space) of the all-new BDJ Jobs and BDJ Marketplace (http://bit.ly/2aVtmga) and a video featuring the $B D J$ 'Graffiti Cover' being made - the cover of issue 1 (8 July) in the current volume, 221.

Visit BDJ Bites at go.nature.com/bdjyoutube.

\title{
Londoners get mouthy in disused railway tunnel
}

In early July the Science

Gallery London (due to open

in London Bridge in 2018)

launched an experimental pre-opening season aimed at making people re-examine their relationship with the mouth. The MOUTHY: INTO THE ORIFICE event ranged

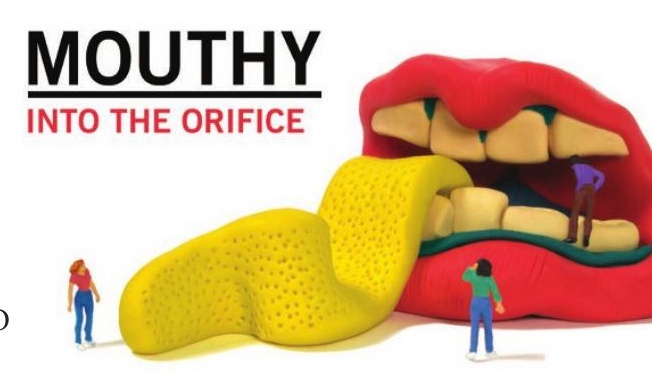
from contemporary dance to performance poetry, immersive installations and workshops.

For the pre-season opening, 'The Orifice' was a pop-up venue in a disused railway tunnel in London Bridge. The main focus in July was saliva: magnifying it, investigating its properties and finding out what it says about us. Among other activities, visitors were asked to contribute their saliva to a collective spit crystal; create a unique cast of their tongue; learn about the science behind kissing; and view unique teeth grown using bacteria.

Further events will run in surprising locations around London Bridge from September to November 2016. For further information visit https://london.sciencegallery.com/mouthy/. 